\title{
'Await' in the pelagic: dynamic trade-off between reproduction and survival within a herring school splitting vertically during spawning
}

\author{
Bjørn Erik Axelsen ${ }^{1,2, *}$, Leif Nøttestad ${ }^{1}$, Anders Fernö $^{2}$, Arne Johannessen ${ }^{2}$, \\ Ole Arve Misund ${ }^{1}$ \\ ${ }^{1}$ Institute of Marine Research, PO Box 1870 Nordnes, 5817 Bergen, Norway \\ ${ }^{2}$ Department of Fisheries and Marine Biology, Bergen High-Technology Centre, 5020 Bergen, Norway
}

\begin{abstract}
Spatio-temporal aspects of spawning behaviour were investigated in a single school of Norwegian spring-spawning herring Clupea harengus, and are explained by changes in the relative importance of reproduction, predation and feeding during spawning. Horizontal area, vertical extension, school shape and relative density were quantified using sonar and echosounder, and related to gonad maturation stage and stomach fullness recorded from gillnet samples. The majority of the herring completed spawning within $3 \mathrm{~d}$. During this period, the herring were feeding and predatory fish were present in the area. An extended cylindrical school shape prior to spawning indicated that individual herring within the school had different depth preferences, with ripe individuals descending towards the spawning substrate on the bottom while immature individuals preferred the pelagic environment for safety and feeding. As the majority of the fish matured, the school segregated vertically into a pelagic component that contracted to a tight ball and a demersal component that spread out in a flat layer on the bottom. Post-spawners seemed to return to the pelagic school. After spawning, the 2 components rejoined each other and formed a loose flake (i.e. loose, uneven layer) at the surface. Schooling fish have traditionally been considered to make 1 of 3 behavioural decisions: to stay, join or leave a school. Waiting without losing contact with the rest of the school, 'await', is suggested as a fourth option.
\end{abstract}

KEY WORDS: Herring $\cdot$ Spawning $\cdot$ Vertical school split $\cdot$ Feeding $\cdot$ Await $\cdot$ Acoustics

Resale or republication not permitted without written consent of the publisher

\section{INTRODUCTION}

The herring Clupea harengus is adapted to a pelagic lifestyle (Harden Jones 1968, Blaxter 1985) and utilises the pelagic environment for feeding and protection through extended horizontal and vertical migrations (Fernö et al. 1998). Schooling behaviour commences at the larval stage and persists throughout the lifespan (Breder 1976, Blaxter \& Hunter 1982, Blaxter 1985, Fuiman \& Magurran 1994, Domenici \& Batty 1997). The fish swim in a synchronised and polarised manner,

*E-mail: bjorna@imr.no minimising the risk of predation (Pitcher 1983), and have an extensive repertoire of anti-predator responses (Pitcher \& Wyche 1983, Pitcher \& Parrish 1993, Vabø \& Nøttestad 1997, Nøttestad \& Axelsen 1999).

Herring spawn demersally (Runnström 1941, Devold 1963), thereby modifying their pelagic lifestyle and regular schooling pattern. Pacific herring Clupea palassi spawn on seaweed and kelp (Hay 1985), whereas Norwegian spring-spawning herring C. harengus use coarse gravel or rocks (Runnström 1941, Polder 1961) with no other shelter than the school. When schools are in contact with the bottom, fewer potential escape routes and difficulties in performing 
coordinated manoeuvres may make the fish more vulnerable to predators than when they are in pelagic schools. Spawners leaving a pelagic school to spawn at the bottom would also suffer from a reduced dilution effect (Pitcher \& Parrish 1993). Stagnancy due to limited and patchily distributed spawning substrate (Runnström 1941) could also increase the risk of predation.

Individual herring should therefore be expected to spend a minimum amount of time at the bottom. Bowers \& Holliday (1961) suggested that Atlantic herring spawn in just 1 batch, and laboratory experiments have shown that egg deposition can be quite rapid in Pacific herring (Stacey \& Hourston 1982). At school level, however, field studies indicate that spawning takes from 1 (Furevik 1976, Johannessen 1986) to several (Aneer et al. 1983, Kjørsvik et al. 1990, Nøttestad et al. 1996) days. There are no reasons why the spawning grounds should initially represent an optimal location in terms of predation risk or feeding opportunities, and over a period of time predators can be attracted (Toresen 1991, Bergstad \& Høines 1998, Høines \& Bergstad 1999) and planktonic food resources may be depleted (Nonacs et al. 1994). Spent herring remaining at the spawning grounds may thus encounter high predation pressure and suboptimal feeding conditions. If each individual chooses the time and location of spawning in accordance with its own situation, the school should be expected to split into multiple subgroups. This could, however, increase the individual risk of predation through a reduced dilution effect (Pitcher \& Parrish 1993).

At the spawning grounds off Karmøy in south-western Norway, Nøttestad et al. (1996) observed spawning herring both in continuous layers at the bottom and in distinct schools above the bottom. The school dynamics of herring throughout the spawning process, however, have not yet been investigated. We monitored the behaviour of a herring school throughout spawning by combining sonar and echosounder observations to resolve the dynamics in 3 dimensions, and relating observed behaviour to gonad maturation stage and stomach fullness recorded from gillnet samples.

\section{MATERIALS AND METHODS}

Observations were made in Bildøy Bay, south-western Norway (Fig. 1), from April 25 to 29, 1994. A single school of herring Clupea harengus was observed acoustically inside the to Bay between 10:00 and 16:00 h (local time) every day, using the (96 GRT) RV 'Hans Brattstrøm' (University of Bergen). The school was tracked using a $164 \mathrm{kHz}$ multi-beam scanning sonar (Kaijo Denki KCH 1827). The transducer consisted of 48 rod elements (crystal), mounted in a $192^{\circ}$ circle sector. The beam width of each element was $4.0^{\circ}$ verti-

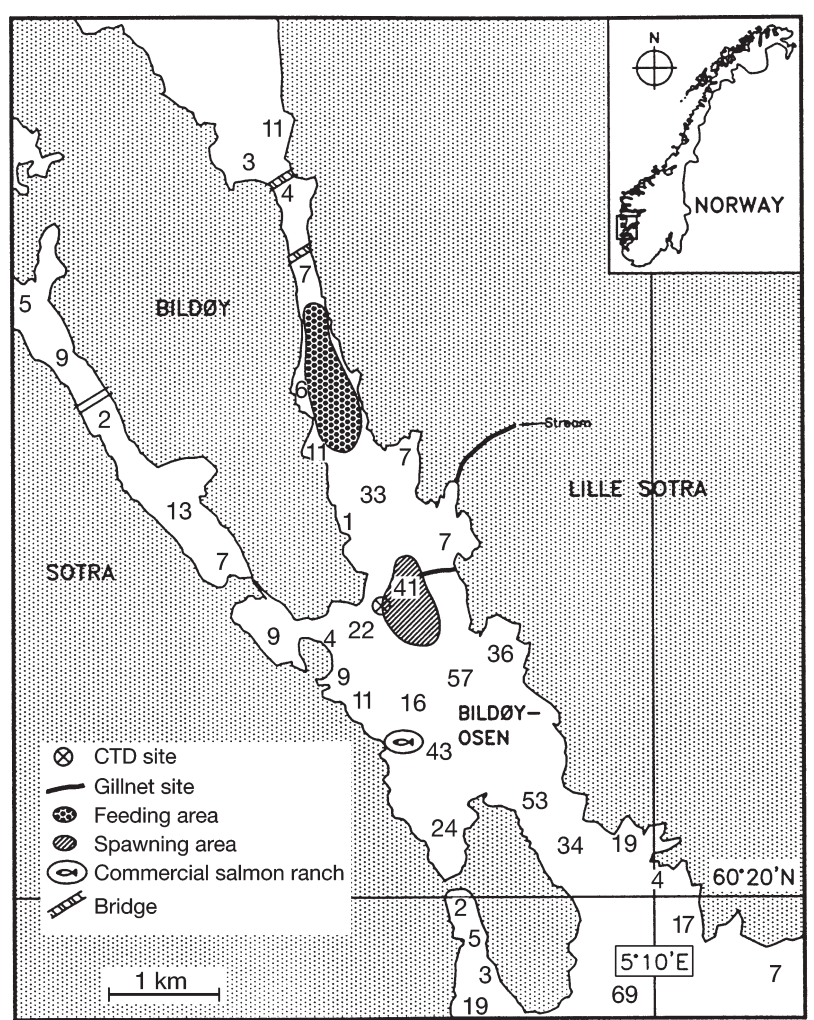

Fig. 1. Map of Bildøy Bay, south-western Norway (depths in metres), showing sampling sites and positions of herring Clupea harengus school as determined acoustically

cally and $30^{\circ}$ horizontally $(-3 \mathrm{~dB})$ during transmission. Pulses were transmitted on 40 elements within a $180^{\circ}$ sector. The pulse duration was 12 to $30 \mathrm{~ms}$ at 100 to $300 \mathrm{~m}$ range. The sonar was set for rotated directed transmission (RDT), a patented beam-forming system that increases the sound pressure with $9 \mathrm{~dB}$ in all directions, from 221 to $230 \mathrm{~dB}$ re $1 \mu \mathrm{Pa}$ at $1 \mathrm{~m}$, compared to omni-directional transmission. During reception, 24 elements are combined in a similar fashion to form a $4.0^{\circ}$ horizontal beam, which scans the $180^{\circ}$ sector clockwise at $1.1 \mathrm{kHz}$. The transducer is tilted mechanically in $1^{\circ}$ steps from 0 to $90^{\circ}$ (vertical). A 38 $\mathrm{kHz}$ single-beam echosounder (Simrad EQ 55) was used to map the vertical orientation and shape of the school. The pulse duration of the echosounder ranged from 0.3 to $1.0 \mathrm{~ms}$ at 50 to $300 \mathrm{~m}$ range. The beam widths were 8.0 and $13.0^{\circ}$ in alongship and athwartship planes, respectively.

The area south of Bildøy was checked daily prior to the recordings in order to determine whether or not other schools were present. The observed school was usually tracked at a distance of 50 to $100 \mathrm{~m}$. The sonar image was recorded on video tape (13 $\mathrm{h}$ in total). Tracks shorter than 10 min were disregarded in order to exclude any vessel-avoidance effects. Freeze-frames 
of the sonar image were analysed every $60 \pm 5 \mathrm{~s}$. Observations biased by bottom echoes were excluded, leaving 397 accepted samples from the footage. A total of 72 printed observations from the echosounder were analysed. Large single-target echoes in the immediate vicinity of the school were interpreted as predatory fish.

The area of the horizontal projection of the school was measured from freeze-frames of the sonar image using a digital light pen. The measurements were corrected for tilt-angle distortion (Misund 1993) and compensated for distance-induced bias using linear regression between vessel-to-school distance $(d)$ and horizontal school area $(a)\left(\mathrm{R}^{2}=0.11, \mathrm{p}<0.001\right.$ [uncompensated]; $\mathrm{R}^{2}=0.00, \mathrm{p}>0.05$ [compensated]):

$$
\text { school area }=a \cdot s^{2} \cdot \cos (\in)-(d \cdot b) \quad\left(\mathrm{m}^{2}\right)
$$

where $s=$ linear scaling factor, $\in=$ tilt angle $\left({ }^{\circ}\right)$ and $b=$ regression coefficient. The relative density (\%) of the school was defined as the extent of the overall school area covered by the core (the densest part of the school, apparent as red colour on the sonar screen). The circularity of the school in the horizontal plane (see Gerlotto et al. 1999) was calculated as:

$$
\text { circularity }=100 \cdot(p /[4 \pi \cdot s \cdot a])^{-1}
$$

where $p=$ school perimeter $(\mathrm{m})$. GPS positions of the school were calculated using position of the vessel, vessel-to-school bearing and horizontal distance. Swimming speed $\left(\mathrm{m} \mathrm{s}^{-1}\right)$ was calculated for consecutive observations $<2$ min apart. The centre depth (CD) of the school was calculated from the sonar and echosounder measurements as:

$$
\text { and } \quad \mathrm{CD}_{\text {SONAR }}=(d \cdot \sin [\in])-t d \quad(\mathrm{~m})
$$

recordings (Table 1). School shapes that did not fall within any of the 4 categories were termed 'amorphous'. Recorded horizontal school extension is affected by both speed of the vessel and swimming speed and swimming direction of the school, but given the distinctiveness off the defined categories, changing school shape over time should be indicative of changes in school structure.

The school was repeatedly sampled using 4 bottom gillnets set in 1 chain. Each gillnet was $25 \mathrm{~m}$ long by $4 \mathrm{~m}$ high, with mesh sizes of 32 to $34 \mathrm{~mm}$ (when stretched with $5 \mathrm{~kg}$ force). The nets were set daily around 16:00 h in the vicinity of the school and hauled in around 09:00 $\mathrm{h}$ the next morning. Setting depth was 40 to $50 \mathrm{~m}$. Total length (10 mm groups) and wet weight $(0.1 \mathrm{~g}$ resolution) of the sampled herring were recorded. Degree of stomach fullness was graded 1 to 5, with 1 corresponding to empty, 2 to low, 3 to intermediate, 4 to high and 5 to full. Gonad maturity index was classified according to the 8-point ICES maturity scale, whereby 1 and 2 are juvenile stages, 3 to 5 prespawning stages, 6 running stage, 7 spent stage, and 8 resting stage (Anonymous 1962).

Available species of zooplankton prey were sampled in a total of 8 parallel vertical plankton hauls in the northern part of Bildøy Bay (Fig. 1) on the last day of the observation period. The samples were taken at the site of the school, from depths of 6 to $14 \mathrm{~m}$ to the surface, using a Juday sampler with $60 \mathrm{~cm}$ (diam.) opening and $180 \mu \mathrm{m}$ net. Two CTD casts were carried out, 1 in Bildøy Bay and 1 in the connecting fjord system. A standard weather report was provided at the nearest meteorological station (Norwegian Meteorological Institute, Flesland).

\section{RESULTS}

respectively, where $t d$ (transducer depth) $=1 \mathrm{~m}, D_{\min }=$ minimum depth of the school $(\mathrm{m})$, and $V_{\text {ECHOSOUNDER }}=$ vertical extension of the school (m). Four different shape categories were defined according to the horizontal-to-vertical extension ratio from the echosounder
During the study period, the weather was cloudy, with south-westerly winds (5 to $8 \mathrm{~m} \mathrm{~s}^{-1}$ ) and small waves (max. $30 \mathrm{~cm}$ ). Below the relatively brackish (salinity

Table 1. Vertical orientation of school components according to shape category ( $H$ : height of school component on echogram (cm);

\begin{tabular}{|c|c|c|c|c|c|c|c|c|}
\hline Category & Definition & $\mathrm{n}$ & $\begin{array}{l}\text { Pel } \\
(\%)\end{array}$ & $\begin{array}{c}\text { Dem } \\
(\%)\end{array}$ & $\begin{array}{l}\text { Depth } \pm \text { SD } \\
(\mathrm{m})\end{array}$ & $\begin{array}{l}\text { Range } \\
\text { (m) }\end{array}$ & $\begin{array}{l}\text { Vert } \pm \text { SD } \\
\quad(\mathrm{m})\end{array}$ & Range \\
\hline Flake & $H: W \leq 1: 3$, pelagic & 15 & 100 & 0 & $3.1 \pm 1.5$ & $2-8$ & $5.3 \pm 2.2$ & $3-11$ \\
\hline Ball & $3: 4 \leq H: W \leq 5: 4$ & 16 & 100 & 0 & $11.8 \pm 4.1$ & $5-23$ & $14.8 \pm 3.9$ & $8-24$ \\
\hline Cylinder & $H: W \geq 3: 1$ & 20 & 90 & 10 & $20.8 \pm 6.8$ & $13-42$ & $21.8 \pm 5.8$ & $13-36$ \\
\hline Carpet & $H: W \leq 1: 3$, demersal & 37 & 0 & 100 & $39.2 \pm 9.7$ & $25-59$ & 2 & \\
\hline Amorphous & Others & 20 & 55 & 45 & $28.7 \pm 17.0$ & $8-57$ & $14.1 \pm 8.9$ & $3-34$ \\
\hline All & & 108 & 69 & 31 & $24.6 \pm 16.0$ & $2-59$ & $10.2 \pm 9.0$ & $2-36$ \\
\hline
\end{tabular}
$W$ : width of school component on echogram $(\mathrm{cm})$; $\mathrm{n}$ : number of observations; Pel: frequency of observations with pelagic component; Dem: frequency of observations with demersal component; Vert: vertical extension of school component (m). All observations of 'Carpet' were estimated at $\sim 2 \mathrm{~m}$ vertical extension 
from 25 to 30 PSU) surface layer (upper $50 \mathrm{~cm}$ ), the water column consisted of cold coastal water. The temperature was highest $\left(5.6^{\circ} \mathrm{C}\right)$ at the surface and at 30 to $35 \mathrm{~m}$ depth and lowest $\left(5.2^{\circ} \mathrm{C}\right)$ at 15 to $20 \mathrm{~m}$ depth and towards the bottom ( $55 \mathrm{~m}$ at the sample site), while the salinity increased steadily towards the bottom (salinity 33 PSU). Mean recorded zooplankton density was 94.2 $\pm 30.5 \mathrm{SD} \mathrm{mg} \mathrm{m}^{-3}$ (total dry $\mathrm{wt}, \mathrm{n}=8$, sampling depth 6 to $14 \mathrm{~m}$ ). Juvenile stages of Calanus finmarchicus dominated the samples. Juvenile Pseudocalanus sp., Acartia sp., Temora sp. and Oithona sp. and eggs of various species were also identified in the samples. A total of 5 to 10 gadoids, all $>50 \mathrm{~cm}$ total length (cod Gadus morhua, haddock Melanogrammus aeglefinus, saithe Pollachius virens) were caught in each gillnet sample.

The biological parameters for the sampled Clupea harengus are summarised in Table 2 . Both sexes were present (50.2\% females, $49.8 \%$ males), and there were no deviations from the binomial distribution of the number of females in each sample $(\alpha \leq 0.05)$. Total length ranged from 250 to $360 \mathrm{~mm}$ (305 $\pm 19 \mathrm{SD})$ and wet weight from 148 to $363 \mathrm{~g}(232 \pm 45)$. Individuals of 3 to $5 \mathrm{yr}$ of age dominated the samples, but 6,7 and $11 \mathrm{yr}$ old individuals (from the strong 1983 year-class) were also present. There was a gradual change from dominance of early-stage maturing individuals to dominance of spent individuals throughout the period, indicating that spawning had taken place (Fig. 2). All the herring were maturing or ripe in the first sample. Two days later, $97 \%$ of the individuals were spent $(77 \%)$ or running $(20 \%)$ and only $3 \%$ were in a prespawning state. In the final sample (1 d later), the proportion of spent herring was the same as on the previous day $(80 \%)$ and $20 \%$ had still not spawned. Of the latter, $10 \%$ were in a pre-spawning stage. The increase in pre-spawners in the last 2 samples suggests some sample bias, but it is evident that a certain proportion of the fish had still to spawn at the time of the final sampling. Fish at all stages of maturity had food in their stomachs, with a slight rise in stomach fullness with increasing maturity $\left(\mathrm{R}^{2}=0.04, \mathrm{p}<0.05\right)$. Stomach fullness increased in the first 3 samples, but was relatively low in the final sample. The pre-spawners in

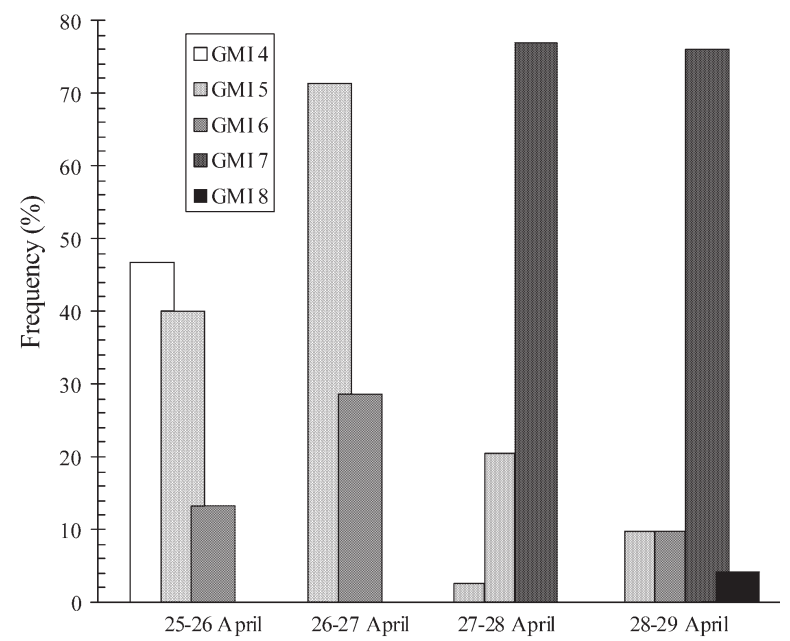

Fig. 2. Clupea harengus. Distribution of gonad maturation indexes (GMI) (Anonymous 1962) in samples. GMI 4,5: prespawning; GMI 6: running; GMI 7: spent; GMI 8: resting

the final sample were not only heavier $(\mathrm{p}<0.05$, Students $t$-test), but also longer $(\mathrm{p}<0.05)$ than postspawners.

Only 1 herring school was recorded, and it remained within Bildøy Bay. The size of the school was estimated to be approximately 5 t, or 15000 to 20000 individuals, based on simple considerations of its geometry and density (Misund et al. 1992). The school moved around somewhat at the beginning of the observation period, became more stationary in the middle of the bay during spawning, and moved to a narrow channel in the northern part of the bay towards the end of the spawning period, where it is believed to have fed on the high concentrations of Calanus finmarchicus (Fig. 1).

The echosounder recordings revealed that the school divided vertically into 2 distinct components, 1 pelagic and 1 demersal, with an inter-component distance that varied between 2 and $30 \mathrm{~m}$ (Fig. 3). On Day 1, the pelagic school was usually vertically extended (cylindrical) whereas the demersal component, when present, was amorphous. On Day 2, both components were initially observed to be amorphous. The pelagic component then resumed a cylindrical shape,

Table 2. Clupea harengus. Biological parameters for pre- and post-spawners (Tot: total). $\alpha$ : level of significance (2-sided) of binomial distribution test). Degree of stomach fullness determined manually: $1=$ empty; $2=$ low; $3=$ intermediate; $4=$ high; $5=$ completely full. In the last sample, only 50 out of 71 otolith pairs could be read

\begin{tabular}{|c|c|c|c|c|c|c|c|c|c|c|c|c|c|c|c|}
\hline \multirow{2}{*}{$\begin{array}{l}\text { Date, } \\
\text { April }\end{array}$} & \multirow{2}{*}{$\overline{\text { Tot } P}$} & \multicolumn{2}{|c|}{$\mathrm{n}$} & \multicolumn{2}{|c|}{ Total length (mm) } & \multicolumn{2}{|c|}{ Wet weight $(\mathrm{g})$} & \multicolumn{2}{|c|}{ Age (years) } & \multicolumn{4}{|c|}{ Females (fraction of total) } & \multicolumn{2}{|c|}{ Stomach fullness (1-5) } \\
\hline & & Pre & Post & Pre \pm SD & Post \pm SD & Pre \pm SD & Post \pm SD & Pre \pm SD & Post \pm SD & Pre & $\alpha$ & Post & $\alpha$ & Pre \pm SD & Post \pm SD \\
\hline 26 & 15 & 15 & 0 & $302.0 \pm 23.7$ & & $243.8 \pm 51.2$ & & $4.73 \pm 1.94$ & & 0.60 & 0.04 & & & $1.9 \pm 0.8$ & \\
\hline 27 & 7 & 7 & 0 & $295.7 \pm 16.2$ & & $242.4 \pm 40.6$ & & $4.14 \pm 1.21$ & & 0.57 & 0.02 & & & $3.1 \pm 1.4$ & \\
\hline 28 & 35 & 6 & 29 & $304.2 \pm 16.3$ & $308 \pm 22.8$ & $248.3 \pm 37.1$ & $232 \pm 52.7$ & $3.83 \pm 0.98$ & $4.24 \pm 1.77$ & 0.67 & 0.03 & 0.45 & 0.01 & $3.7 \pm 1.2$ & $3.9 \pm 1.2$ \\
\hline 29 & 71 & 14 & 57 & $316.4 \pm 13.9$ & $302 \pm 17.0$ & $273.3 \pm 40.7$ & $216 \pm 33.9$ & $4.73 \pm 2.20$ & $4.10 \pm 0.79$ & 0.36 & 0.01 & 0.46 & 0.03 & $2.3 \pm 1.2$ & $2.8 \pm 1.1$ \\
\hline
\end{tabular}



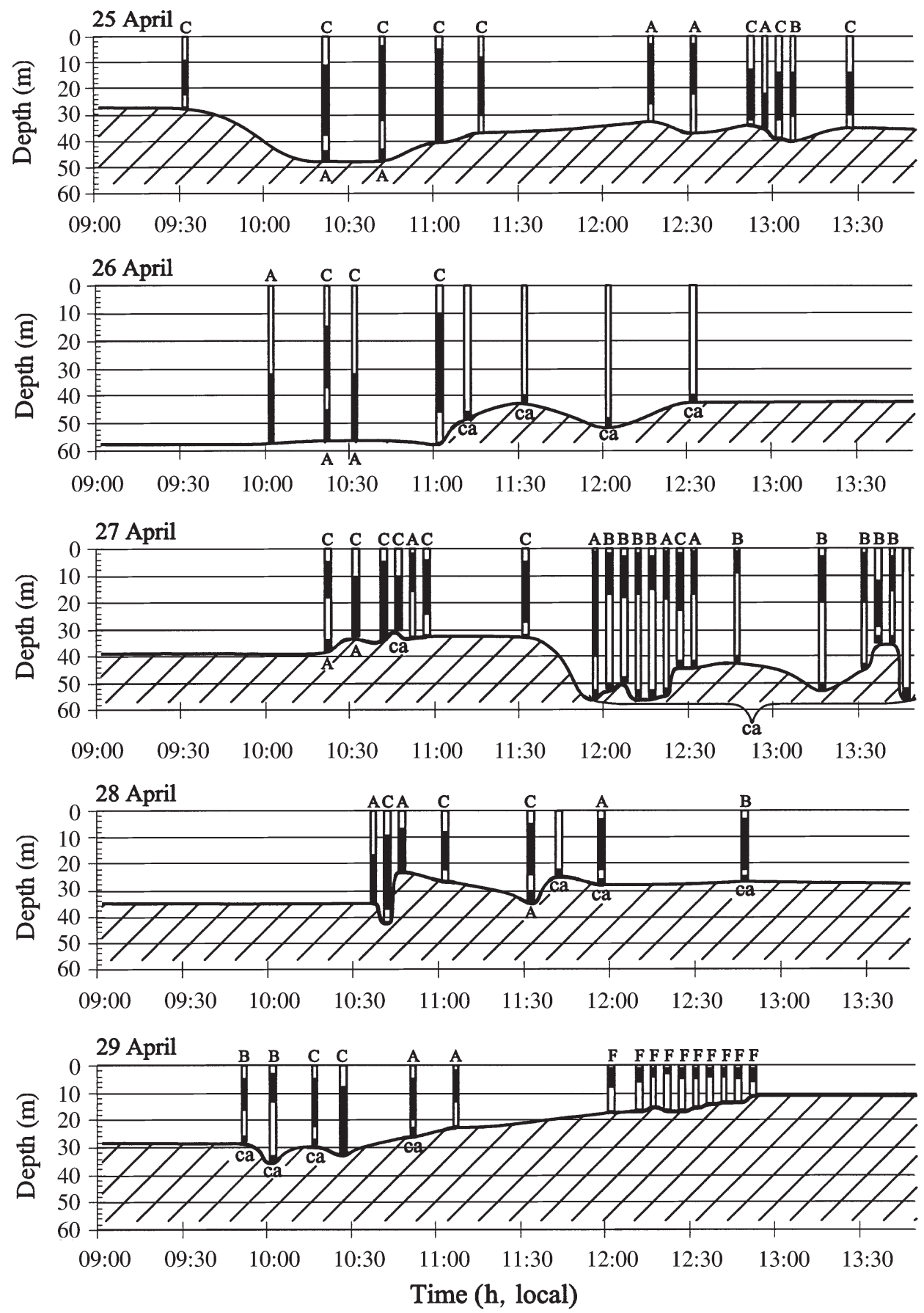

Fig. 3. Clupea harengus. Vertical position of school components ( $\square$ ) in water column ( $\square$ ) during study period. Where present, shape categories (A: 'amorphous'; B: 'ball'; C: 'cylinder'; F: 'flake' [i.e. loose, uneven layer]; ca: 'carpet') are indicated above and below each observation for pelagic and demersal components, respectively. Bottom line is fitted

but was not visible during the last 4 observations on this day. During these observations, however, the demersal component was visible as a carpet-shaped layer at the bottom. Temporary reconnections of the 2 components were observed at the beginning of Day 3, but around noon the school divided into a stable ball/carpet configuration. This coincided with the peak of spawning in the biological samples (Fig. 2), strongly suggesting that ripe fish parted from the main school and congregated on the bottom to spawn. As the majority of the fish completed spawning, the shape of the pelagic component again became dynamic, alter- 


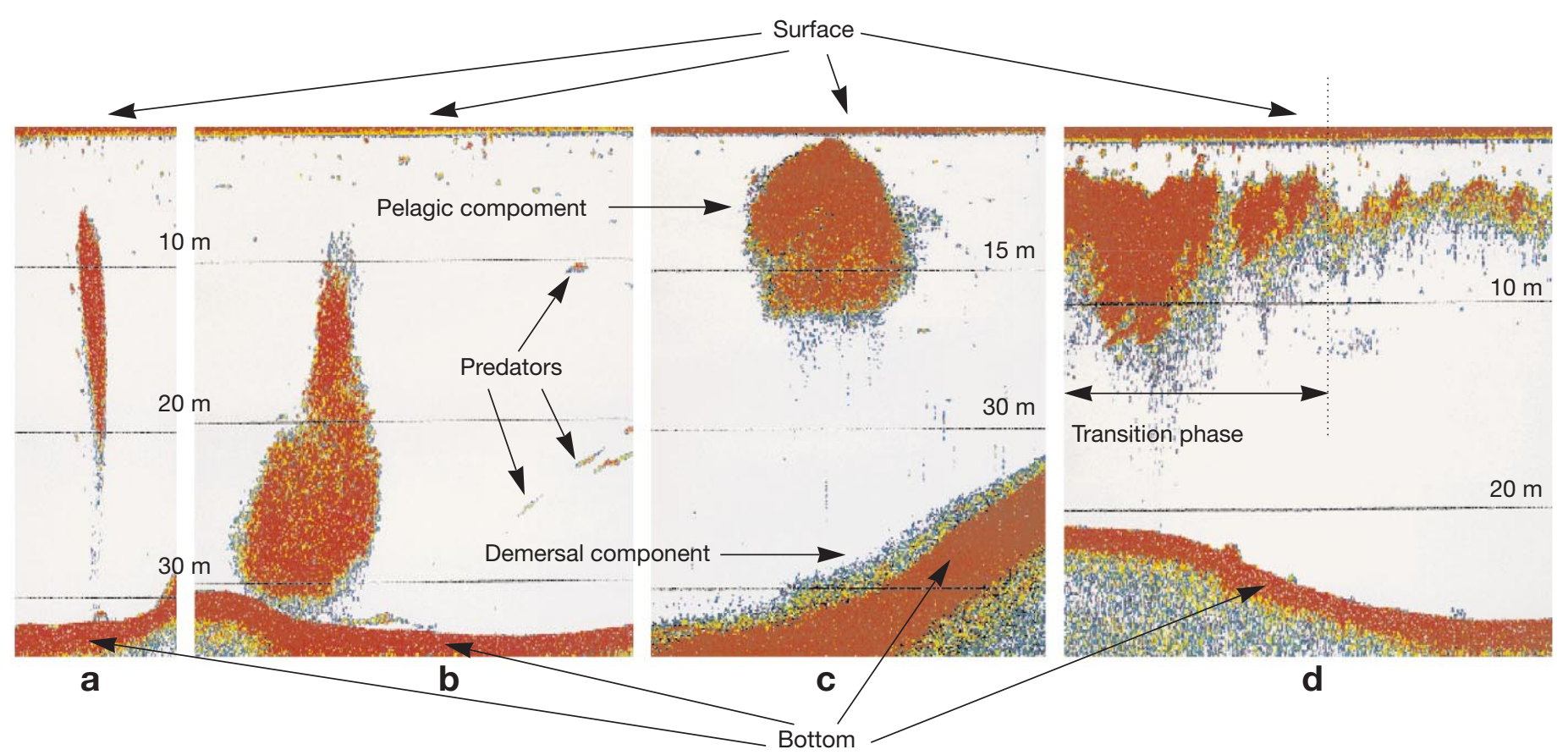

Fig. 4. Clupea harengus. School shapes typically observed throughout the period. (a) 'Cylinder' (note thin connection from school towards bottom); (b) 'amorphous'; (c) pelagic component ('ball') and demersal component ('carpet'); (d) 'flake' (this was the first observation of 'flake', note that school restructured during a 'transition phase' before resuming 'flake' shape). Examples of singletarget echoes interpreted as predatory fish are indicated in (b). Note depth scale in (c)

nating between amorphous, cylindrical and ball-like, before the school reorganised as a stable flake at the surface at the end of the period. No demersal component was then observed. Typical examples of echogram prints at different stages of the spawning process are given in Fig. 4.

The pelagic component could be detected by both sonar and echosounder. A summary of the acoutic parameters is given in Table 3. The horizontal area of the

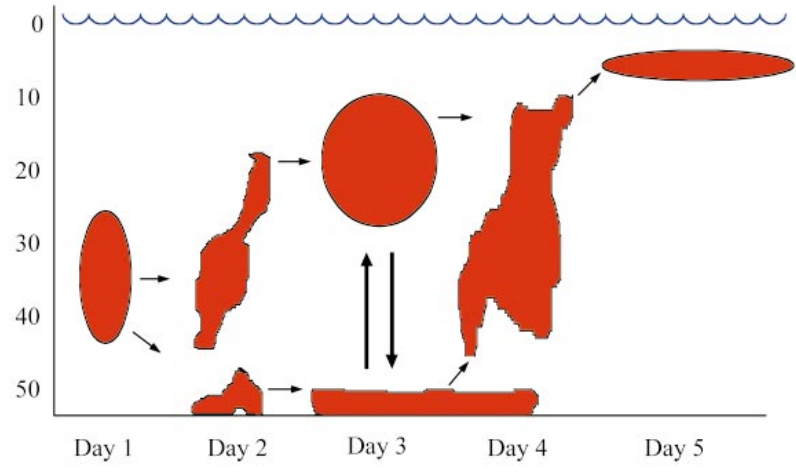

Maturing

Ripe

Spent

Fig. 5. Clupea harengus. Schematic illustration of spawning dynamics. Short arrows: change of dominant shape category from day to day; long arrows: suggested exchange of fish between pelagic and demersal school component. Depths (ordinate) are in metres pelagic component was about $240 \mathrm{~m}^{2}$ during the first $2 \mathrm{~d}$ and about $550 \mathrm{~m}^{2}$ during the last $3 \mathrm{~d}$. The center depth was quite different between the sonar and the echosounder in the first $2 \mathrm{~d}$, but both instruments indicated that the school ascended through the water column during the period. Vertical extension decreased throughout the period, supporting the idea that the herring ascended and the school flattened out. The relative density of the school was higher before spawning ( $41 \%$ on the first day) than after $(25 \%$ on the last day, $\mathrm{p}<0.001$; Mann-Whitney $U$-test, Bonferroni correction of $\alpha$-level), while swimming speed and circularity showed little variation. The shape categories were associated with distinct depth intervals (Tukey HSD test with unequal $\mathrm{n}, \mathrm{p}<0.001$, Table 1). A visual interpretation of the spawning dynamics is given in Fig. 5.

\section{DISCUSSION}

To the best of our knowledge this is the first in situ study of the complete spawning process of herring at school level. The school completed spawning within $3 \mathrm{~d}$, in agreement with previous studies indicating that spawning takes from 1 (Furevik 1976, Johannessen 1986) to several (Aneer et al. 1983, Nøttestad et al. 1986, Kjørsvik et al. 1990) days. During spawning, the school divided vertically, forming a pelagic school and a distinct, demersal layer. 
Table 3. Clupea harengus. Acoustic parameters for the pelagic school component

\begin{tabular}{|c|c|c|c|c|c|c|}
\hline Parameter & 25 April & 26 April & 27 April & 28 April & 29 April & All \\
\hline \multicolumn{7}{|l|}{ Sonar } \\
\hline \multicolumn{7}{|c|}{ School area $\left(\mathrm{m}^{2}\right)$} \\
\hline Mean & 237 & 249 & 566 & 525 & 588 & 444 \\
\hline SD & 135 & 146 & 278 & 192 & 400 & 278 \\
\hline Min. & 67 & 23 & 79 & 130 & 28 & 23 \\
\hline Max. & 541 & 930 & 1284 & 952 & 1513 & 1513 \\
\hline \multicolumn{7}{|c|}{ Relative density (\%) } \\
\hline Mean & 41 & 28 & 37 & 38 & 25 & 33 \\
\hline $\mathrm{SD}$ & 16 & 11 & 15 & 12 & 11 & 14 \\
\hline Min. & 19 & 6 & 5 & 8 & 7 & 5 \\
\hline Max. & 71 & 58 & 69 & 75 & 50 & 75 \\
\hline \multicolumn{7}{|c|}{ Circularity (\%) } \\
\hline Mean & 65 & 67 & 59 & 65 & 69 & 64 \\
\hline $\mathrm{SD}$ & 17 & 15 & 14 & 14 & 13 & 15 \\
\hline Min. & 41 & 24 & 23 & 39 & 31 & 23 \\
\hline Max. & 85 & 96 & 99 & 92 & 90 & 99 \\
\hline \multicolumn{7}{|c|}{ Swimming speed $\left(\mathrm{m} \mathrm{s}^{-1}\right)$} \\
\hline Mean & 0.96 & 0.90 & 0.77 & 0.95 & 0.54 & 0.84 \\
\hline SD & 0.63 & 0.62 & 0.51 & 0.67 & 0.46 & 0.60 \\
\hline Min. & 0.20 & 0.07 & 0.07 & 0.04 & 0.08 & 0.04 \\
\hline Max. & 2.2 & 3.1 & 3.4 & 3.1 & 2.3 & 3.4 \\
\hline \multicolumn{7}{|c|}{ Centre depth (m) } \\
\hline Mean & 34 & 17 & 13 & 8.5 & 9.6 & 14 \\
\hline $\mathrm{SD}$ & 11 & 8.4 & 4.7 & 5.5 & 11.8 & 8.9 \\
\hline Min. & 13 & 1 & 3 & 1 & 1 & 1 \\
\hline Max. & 60 & 33 & 26 & 23 & 49 & 60 \\
\hline \multicolumn{7}{|c|}{ Echosounder } \\
\hline \multicolumn{7}{|c|}{ Centre depth (m) } \\
\hline Mean & 21.5 & 37.6 & 13.8 & 10.7 & 9.2 & 14.9 \\
\hline SD & 4.5 & 10.1 & 4.8 & 7.5 & 9.7 & 10.1 \\
\hline Min. & 13.5 & 27.0 & 6.0 & 2.5 & 3.0 & 2.5 \\
\hline Max. & 29.0 & 46.5 & 24.5 & 23.0 & 42.5 & 46.5 \\
\hline \multicolumn{7}{|c|}{ Vertical extension (m) } \\
\hline Mean & 21.1 & 25.2 & 17.6 & 12.0 & 9.2 & 15.5 \\
\hline SD & 6.7 & 3.4 & 6.4 & 8.0 & 5.6 & 10.1 \\
\hline Min. & 13.0 & 22.0 & 8.0 & 3.0 & 4.0 & 3.0 \\
\hline Max. & 35.9 & 30.0 & 34.0 & 24.0 & 23.0 & 35.9 \\
\hline
\end{tabular}

were restricted to daytime, and consequently potential diurnal trends could not be investigated.

On a few occasions (the last 4 observations on Day 2 and the last observation on Day 3), the pelagic component was not detected by the echosounder (Fig. 3). One explanation may be that all the herring were at the bottom, but that seems somewhat unlikely since a pelagic component was present during all other observations. Another explanation could be horizontal vessel avoidance (i.e. Olsen et al. 1983, Misund 1990, Misund \& Aglen 1992, Fréon et al. 1993), but it may also simply have been due to the narrow beam width close to the surface. The school did not appear vigilant during tracking, and diving, which is a primary avoidance reaction in shallowly distributed herring in particular (Olsen et al. 1983, Misund \& Aglen 1992), was not observed.

Combining school dynamic parameters and information about gonad maturity stage offered a good opportunity for studying herring behaviour at different levels of the spawning process. The gillnets were fishing from the bottom and $4 \mathrm{~m}$ upwards at night, and the entire school may therefore not have been properly sampled. The vertical distribution of the herring during the night is not known, but if the vertical division persisted during the night, the proportion of ripe individuals may have been positively biased due to higher abundance of ripe and spawning fish at the bottom. If the herring dispersed pelagically, the samples should not be biased. The samples should in any case give a relative index of the change in gonad maturation stage. This is supported by the steady progression in gonad maturity recorded during the period.

No other schools were observed in the area. Even though Norwegian spring-spawning herring generally gather in dense aggregations along the coast to spawn (Devold 1963, 1967, Dragesund 1970, Dragesund et al. 1980, Nøttestad et al. 1996), isolated herring schools do, thus, exist. Our observations are primarily relevant to such solitary schools, but dense aggregations of spawning herring distributed in demersal layers and pelagic schools have been previously observed (Nøttestad et al. 1996, Slotte 1998), indicating that our findings are representative for herring spawning dynamics during daytime. 


\section{School shape}

Prior to spawning, the shape of the school was predominantly cylindrical, and stretched out in the vertical plane. Fish schools are usually horizontally elongated (Wrzesinski 1972, Misund 1993, Nøttestad et al. 1996) but vertically extended fish schools have been observed (Wrzesinski 1972). Individual herring at different stages of maturity may prefer different positions in the water column, with ripening fish searching towards the bottom and early maturing fish aggregating in the pelagic. However, staying with the group could be more important than vertical position alone, causing the school to stretch out in the vertical plane.

Cylindrical shape during the first day was followed by a predominately amorphous shape the following day. At this point, the school divided into 2 vertically distinct components. The amorphous shape may have resulted from reduced synchrony and polarity in the school (Pitcher \& Parrish 1993) as individuals were about to break out of the pelagic school to spawn on the bottom. The subsequent tight ball formation of the pelagic school component may have been the result of individuals seeking protection within the school (Pitcher \& Wyche 1983, Fréon et al. 1992, Parrish 1992, Pitcher \& Parrish 1993, Nøttestad \& Axelsen 1999).

\section{Partial vertical school split}

Traditionally, schooling fish have been regarded as making a behavioural decision to stay, join or leave a school (Pitcher \& Parrish 1993). However, for an obligate schooling species such as herring, all 3 choices may not exist, or may be suboptimal. To stay is always possible, but beneficial only if local conditions are favourable. To leave is advantageous only if a sufficiently large group can leave simultaneously (split), whereas to join depends on the presence of other schools in the vicinity (Pitcher et al. 1996). Because of the enhanced predation risk at the bottom, particularly during daytime, maturing individuals should benefit from remaining in the pelagic for as long as possible before spawning. In their laboratory experiment, Stacey \& Hourston (1982) observed individual Pacific herring Clupea harengus pallasi to keep contact with the school until 'surface testing' or 'surface spawning' commenced. Spent fish may be better off mingling with the group of pre-spawners than taking their chance on their own when no other schools are nearby. We suggest a fourth strategy for pre- and postspawners in the pelagic: waiting without losing contact with the group ('await').

A new observation in this study was the partial splitting of a fish school into pelagic and demersal compo- nents. Although we could not take samples from the different divisions, it is reasonable to assume that the demersal component was dominated by spawning fish and the pelagic component by pre- and post-spawners. Herring are known to spawn close to the bottom (Runnstrøm 1941, Devold 1963). Before spawning started, the pelagic school component must have consisted of pre-spawning fish, and observations of $40 \mathrm{t}$ of herring spawning in a net cage have shown that post-spawning fish move close to the surface (Nøttestad unpubl. obs.). The temporary reconnections of the components are interpreted in terms of fish descending to the bottom to spawn and fish ascending after spawning.

School splitting has previously only been observed in the horizontal plane (Pitcher \& Parrish 1993, Nøttestad et al. 1996, Pitcher et al. 1996, Misund et al. 1998). Schools in the pelagic have been observed to remain in contact between splitting and rejoining events (Pitcher et al. 1996), but for a much shorter time (minutes) than the contact observed between the 2 divisions of the spawning school (days). For schools splitting vertically close to the bottom, visual contact between school components may be maintained, since the bottom prevents further downward movements and the spawning substrate is spatially restricted. Although it had split into 2 components, the school seemed to remain as 1 unit during spawning. There were no indications that spent individuals left the school. No echoes outside the school characterised as herring were detected, and the estimated school area actually increased during the course of the spawning period, presumably because the school flattened out.

Predation is considered the primary evolutionary force that shapes schooling behaviour in pelagic fish species (Fuiman \& Magurran 1994). During the herring spawning period, several piscivores and benthivores have been reported as showing shifts in diet, abandoning their normal prey in favour of herring at both egg and adult stages (Høines et al. 1995, Høines \& Bergstad 1999). Potential predators of herring were observed acoustically and were present in the gillnet samples as well. The predation risk is presumably relatively high during spawning because of reduced polarity during spawning (Aneer et al. 1983) and restricted escape possibilities close to the bottom. The larger area-to-volume ratio in a horizontally flattened spawning layer (carpet) compared to a more spherical pelagic school (ball) may further enhance predation risk (Parrish 1992).

While they are spawning, herring need to keep in contact with the bottom in order to shed their eggs on the substrate (Runnstrøm 1941). The relative costs and benefits of staying at the bottom ought therefore to change throughout the spawning period, being different for fish at various stages of maturity. This con- 
flict of interests between individual fish within the school could partly be resolved by the formation of vertical divisions. The ascent of the pelagic component throughout the period may be explained in terms of a rising proportion of spent fish being progressively less attracted to the bottom. Individual positional preferences in fish schools have earlier been postulated (Magurran 1993) and, to some extent, observed (Krause 1993), but to the best of our knowledge the present study is the first report of a fish school in which individuals in different states move apart while maintaining contact for a period of several days.

Ripening fish might be expected to wait above the spawning substrate to spawn, but why do postspawners not leave the area? Although herring often move between schools of different size and composition (Pitcher et al. 1996), they are unlikely to leave a school unless there are other schools to join or a sufficiently large group can leave together, since otherwise they can suffer increased risk of predation (Fernö et al. 1998). Staying with the group may be more important than optimising individual demands, and spent individuals may thus benefit by remaining with a school at a site that is suboptimal with regard to feeding opportunities and predation.

Spent fish may not always wait until all the fish in the school have spawned. If other schools are nearby, spent fish from different schools might reorganise themselves into a new school. High predation pressure and poor feeding conditions on the spawning grounds might increase the probability of leaving. If a sufficiently large number of spent fish would leave the school, their decisions could be transferred to prespawners. About $20 \%$ of the fish in the school in our study had not yet spawned on the last sampling occasion. Even if the gillnets at the bottom overestimated the number of pre-spawners, and some fish spawned during the interval between final sampling and the school leaving the spawning site, this still suggests that some fish left without having spawned.

\section{Feeding}

Although feeding before spawning has been reported in spring-spawning herring Clupea harengus in Minas Basin, Nova Scotia (Bradford \& Iles 1992), it has generally been believed that herring do not feed prior to spawning but start shortly after (Parsons \& Hodder 1975, Crawford 1980, Huse \& Ona 1996, Nøttestad et al. 1996, Slotte 1999), in connection with a change in the trade-off between feeding and reproduction before and after spawning (Nøttestad et al. 1996). As the gut evacuation rate in Atlantic herring is quite short when feeding on copepods $(<3 \mathrm{~h}$ in her- ring larvae; Pedersen 1984), the present study demonstrates that Atlantic herring may feed both before and after spawning. The high concentrations of zooplankton in Bildøy Bay may have permitted the herring to filter-feed (Gibson \& Ezzi 1985, 1992). Using this feeding technique, a pelagic herring school may combine predator defence and feeding (see Magurran 1993). Feeding on the spawning grounds may thus depend on food availability and abundance, and not on gonad maturation stage alone.

\section{Timing of spawning}

Because of the increased risk of predation, individual herring might be expected to spend as little time as possible on the seabed. Although the literature is inconclusive concerning the duration of individual spawning, Atlantic herring seem to be capable of spawning quickly (Harden Jones 1968) and even in 1 batch (Bowers \& Holliday 1961). In our study, the prevalence of maturing individuals in the second sample and of spent individuals in the third sample indicated that individual herring spawned within a maximum of 1 d. At school level, however, spawning lasted for several days. Although a spawning period of $3 \mathrm{~d}$ represents a considerable degree of synchronisation compared to the duration of the spawning period in Norwegian spring spawning herring of about $4 \mathrm{wk}$ at the population level (Devold 1967, Johannessen et al. 1995), one may ask why a herring school does not spawn within a shorter period of time. However, selection pressure towards synchronised maturation need not necessarily result in perfect timing of spawning. The reorganisation of schools by means of splits and joins (Pitcher et al. 1996) may increase synchronisation, but the availability of other schools can be restricted. The maturing process could be synchronised by pheromones (Scott et al. 1994), but the fish in a school may not have been in contact for long. The strength of the selective forces is also unknown, with variable costs of waiting in the pelagic. Furthermore, if the spawning substrate is limited, not all the fish in a school might be able to spawn simultaneously.

Another possibility is that the success of spawning depends on the spawning time, with the individual herring adopting a waiting game (see Maynard Smith 1982). Herring often lay their eggs in sheets on top of each other, forming thick layers on the spawning substrate (Runnström 1941). Eggs laid early may be covered completely and therefore develop slowly (Johannessen 1986, Stratoudakis et al. 1998) and suffer high mortality (Taylor 1971). Delaying spawning and depositing its eggs in the uppermost layer may thus increase an individual's reproductive success. On the 
other hand, waiting too long before spawning may incur other risks. An individual can be caught by predators before spawning, and the school may leave the area when most fish have spawned. Size differences can lead to differences in payoffs (Maynard Smith 1982), and interestingly, in this study the prespawners in the final sample were of significantly greater length than the post-spawners.

\section{Concluding remarks}

The changes over time in horizontal school area, depth, vertical extension and shape observed in this study demonstrate the dynamics of a spawning herring school. Differences in the state of individual fish within a school seem to be reflected in individual position preferences that influence the shape of a school, eventually leading to partial vertical school splitting, which in our view demonstrates multiple trade-offs between reproduction, predation and feeding (see Sih et al. 1998). To the best of our knowledge, the finding that fish schools form distinct, stable subgroups is new. Despite conflicts between individuals, schooling fish can reach compromises in their demands and remain in contact during a period of several days. This illustrates just how greatly individual fish in a school depend on each other, especially when there are no other close schools to join (fish breaking away in small groups would presumably run a high risk of predation). This explains why herring stay at the spawning grounds in a presumably suboptimal locality with respect to predation and food, waiting in the pelagic for the other fish in the school to spawn, and supports the suggestion that a school of herring generally makes collective decisions even if the optimal situation differs for individual fish (Fernö et al. 1998). Biologists have traditionally focused on competition and aggression as determining factors of survival, but cooperation may play a greater role than previously believed (Michod 1999).

Acknowledgements. Svend Lemvig at the Institute of Marine Research is greatly thanked for his valuable help in finding a suitable study site and for reading the otoliths. We are also most thankful for the help of Anne-Britt Skaar Tysseland and Jofrid Øvredal in editing the figures.

\section{LITERATURE CITED}

Aneer G, Florell G, Kautsky U, Nellbring S, Sjöstedt L (1983) In-situ observations of Baltic herring (Clupea harengus membras) spawning behaviour in the Askö-Landsort area, northern Baltic proper. Mar Biol 74:105-110

Anonymous (1962) Recommendations adopted by the Herring Committee. Rapp P-V Réun Cons Perm Int Explor Mer (Appendix 1):71-73
Bergstad OA, Høines ÅS (1998) Do herring (Clupea harengus L.) spawners influence the migratory behaviour of cod (Gadus morhua L.)? ICES J Mar Sci 55:325-328

Blaxter JHS (1985) The herring: a successful species? Can J Fish Aquat Sci 42(1):21-30

Blaxter JHS, Hunter JR (1982) The biology of the clupeoid fishes. Adv Mar Biol 20:1-224

Bowers AB, Holliday FGT (1961) Histological changes in the gonad associated with the reproductive cycle of the herring (Clupea harengus). Mar Res 5:1-16

Bradford RG, Iles TD (1992) Unique biological characteristics of spring spawning herring (Clupea harengus) in Minas Basin, Nova Scotia, a tidally dynamic environment. Can J Zool 70:641-648

Breder CM Jr (1976) Fish schools as operational structures. Fish Bull US 74:471-502

Crawford RH (1980) A biological analysis of herring from the Atlantic coast of Nova Scotia and Eastern Northumberland Strait. Department of Fisheries, Halifax, NS (Manuscript Tech Rep Ser)

Devold F (1963) Life history of the Atlanto-Scandian herring. Rapp P-V Réun Cons Perm Int Explor Mer 154:98-108

Devold F (1967) The behaviour of the Norwegian tribe of Atlanto-Scandian herring. FAO Fish Rep 62:534-549

Domenici P, Batty RS (1997) Escape behaviour of solitary herring (Clupea harengus) and comparisons with schooling individuals. Mar Biol 128:29-38

Dragesund O (1970) Factors influencing year-class strength of Norwegian spring spawning herring (Clupea harengus). FiskDir Skr (Ser HavUnders) 15:381-450

Dragesund O, Hamre J, Ulltang Ø (1980) Biology and population dynamics of the Norwegian spring-spawning herring. Rapp P-V Réun Cons Int Explor Mer 177:43-71

Fernö A, Pitcher TJ, Melle V, Nøttestad L, Mackinson S, Hollingworth C, Misund OA (1998) The challenge of the herring: making optimal collective spatial decisions. Sarsia 83:149-167

Fréon P, Gerlotto F, Soria M (1992) Changes in school structure according to external stimuli: description and influence on acoustic assessment. Fish Res 15:45-66

Fréon P, Gerlotto F, Soria M (1993) Variability of Harengula spp. school reactions to boats or predators in shallow waters. ICES Mar Sci Symp 196:30-35

Fuiman LE, Magurran AE (1994) Development of predator defences in fishes. Rev Fish Biol Fish 4:145-183

Furevik DM (1976) Beskrivelse av adferd i gyteperioden og undersøkelser på de tidlige stadier hos sild (Clupea harengus) i Lindaaspollene. Master thesis, Norges Fiskerihøgskole/University of Bergen (in Norwegian)

Gerlotto F, Soria M, Fréon P (1999) From two dimensions to three: the use of multibeam sonar for a new approach in fisheries acoustics. Can J Fish Aquat Sci 56(1):6-12

Gibson RN, Ezzi IA (1985) Effect of particle concentration on filter- and particulate feeding in the herring Clupea harengus. Mar Biol 88:109-116

Gibson RN, Ezzi IA (1992) The relative profitability of particulate and filter-feeding in the herring Clupea harengus. J Fish Biol 40:577-590

Harden Jones FR (1968) Fish migration. Edward Arnold Ltd, London

Hay DE (1985) Reproductive biology of Pacific herring (Clupea harengus pallasi). Can J Fish Aquat Sci 42(Suppl 1): 111-126

Høines ÅS, Bergstad OA (1999) Resource sharing among cod, haddock, saithe and pollack on a herring spawning ground. J Fish Biol 55(6):1233-1257

Høines ÅS, Bergstad OA, Albert OT (1995) The food web of a 
coastal spawning ground of the herring (Clupea harengus). In: Skjoldal HR, Hopkins C, Erikstad KE, Leinaas HP (eds) Ecology of fjords and coastal waters. Proceedings of the Mare Nor Symposium on the Ecology of Fjords and Coastal Waters. Elsevier Science, Amsterdam, p 17-22

Huse I, Ona E (1996) Tilt angle distribution and swimming speed of wintering Norwegian spring spawning herring. ICES J Mar Sci 53:863-873

Johannessen A (1986) Recruitment studies of herring (Clupea harengus) in Lindaaspollene, Western Norway, 1-3. FiskDir Skr (Ser HavUnders) 18:139-240

Johannessen A, Slotte A, Bergstad OA, Dragesund O, Røttingen I (1995) Reappearance of Norwegian spring spawning herring (Clupea harengus) at spawning grounds off southwestern Norway. In: Skjoldal HR, Hopkins C, Erikstad KE, Leinaas HP (eds) Ecology of fjords and coastal waters. Proceedings of the Mare Nor Symposium on the Ecology of Fjords and Coastal Waters. Elsevier Science, Amsterdam, p 347-363

Kjørsvik E, Lurås IJ, Hopkins CCE, Nilssen EM (1990) On the intertidal spawning of Balsfjord herring (Clupea harengus). ICES Comm Meet Pelagic Fish Comm 1990/ $\mathrm{H}: 30$

Krause J (1993) Positioning behaviour in fish shoals - a costbenefit analysis. J Fish Biol 43:309-314

Magurran AE (1993) Individual differences in fish behaviour. In: Pitcher TJ (ed) Behaviour of teleost fishes, 2nd edn. Chapman \& Hall, New York, p 441-477

Mann KH, Lazier JRN (1991) Dynamics of marine ecosystems. Blackwell Science Publications, Boston

Maynard Smith J (1982) Evolution and the theory of games. Cambridge University Press, Cambridge

Michod RE (1999) Darwinian dynamics. Evolutionary transitions in fitness and individuality. Princeton University Press, Princeton

Misund OA (1990) Sonar observations of schooling herring: school dimensions, swimming behaviour, and avoidance of vessel and purse seine. Rapp P-V Réun Cons Perm Int Explor Mer 189:135-146

Misund OA (1993) Dynamics of moving masses; variability in packing density, shape and size among pelagic schools. ICES J Mar Sci 50:145-160

Misund OA, Aglen A (1992) Swimming behaviour of fish schools in the North Sea during acoustic surveying and pelagic trawl sampling. ICES J Mar Sci 49:325-334

Misund OA, Aglen A, Beltestad K, Dalen J (1992) Relationships between the geometric dimensions and the biomass of schools. ICES J Mar Sci 49:305-315

Misund OA, Fernö A, Pitcher TJ, Totland B (1998) Tracking herring schools with a high resolution sonar. Variations in horizontal area and relative echo intensity. ICES J Mar Sci 54:58-66

Nonacs P, Smith PE, Bouskila A, Luttbeg B (1994) Modelling the behaviour of the northern anchovy, Engraulis mordax, as a schooling predator exploiting patchy prey. Deep-Sea Res (II) 41:147-169

Nøttestad L, Axelsen BE (1999) Herring schooling manoeuvres in response to killer whale attack. Can J Zool $77: 1540-1546$

Nøttestad L, Aksland M, Beltestad A, Fernö A, Johannesen A, Misund OA (1996) Schooling dynamics of Norwegian spring spawning herring (Clupea harengus) in a coastal spawning area. Sarsia 80:277-284

Olsen K, Angell J, Løvik A (1983) Quantitative estimations of the influence of fish behaviour on acoustically determined fish abundance. FAO Fish Rep 300:139-149

Parrish JK (1992) Do predators 'shape' fish schools: interactions between predators and their schooling prey. Neth J Zool 42:358-370

Parsons LS, Hodder VM (1975) Biological characteristic of south-western Newfoundland herring, 1965-71. International Commission for the Northwest Atlantic Fisheries, Dartmouth, NS, p 145-160 (Resources Bulletin No 11)

Pedersen BH (1984) The intestinal evacuation rates of larval herring (Clupea harengus L.) predating on wild plankton. Dana 3:21-30

Pitcher TJ (1983) Heuristic definitions of shoaling behaviour. Anim Behav 31:611-613

Pitcher TJ, Parrish JK (1993) Functions of shoaling behaviour in teleosts. In: Pitcher TJ (ed) The behaviour of teleost fishes, 2nd edn. Croom Helm, London, p 364-439

Pitcher TJ, Wyche CJ (1983) Predator avoidance behaviour of sand-eel schools: why schools seldom split. In: Noakes DLG, Lindquist BG, Helfman GS, Ward JA (eds) Predators and prey in fishes. Junk, The Hague, p 193-204

Pitcher TJ, Misund OA, Fernö A, Totland B, Melle W (1996) Adaptive behaviour of herring schools in the Norwegian Sea as revealed by high-resolution sonar. ICES J Mar Sci 53:449-452

Polder JJW (1961) Cyclical changes in testes and ovary related to maturity stages in the North Sea herring, Clupea harengus. Arch Néerl Zool 14:45-60

Runnström S (1941) Quantitative investigations on herring spawning and its yearly fluctuations at the west coast of Norway. FiskDir Skr (Ser HavUnders) 6(8):5-71

Scott AP, Lilley NR, Vermeirssen ELM (1994) Urine of reproductively mature female rainbow trout, Oncorhynchus mykiss (Walbaum), contains a priming pheromone which enhances plasma-levels of sex steroids and gonadotropin II in males. J Fish Biol 44:131-147

Sih A, Englund G, Wooster D (1998) Emergent impact of multiple predators on prey. Trends Ecol Evol 13:350-355

Slotte A (1998) Patterns of aggregation in Norwegian spring spawning herring (Clupea harengus) during the spawning season. ICES Comm Meet 1998/J:32

Slotte A (1999) Differential utilisation of energy during wintering and spawning migration in Norwegian spring spawning herring. J Fish Biol 54:338-355

Stacey NE, Hourston AS (1982) Spawning and feeding behaviour of captive Pacific herring (Clupea harengus pallasi). Can J Fish Aquat Sci 39:489-498

Stratoudakis Y, Gallego A, Morrison JA (1998) Spatial distribution of developmental egg ages within a herring Clupea harengus spawning ground. Mar Ecol Prog Ser 174:27-32

Taylor FHC (1971) Variation in hatching success in Pacific herring (Clupea harengus pallasi) eggs with water depth, temperature, salinity, and egg mass thickness. Rapp P-V Réun Cons Perm Int Explor Mer 160:34-41

Toresen R (1991) Predation on the eggs of Norwegian springspawning herring (Clupea harengus) on a spawning ground on the west coast of Norway. ICES J Mar Sci 48: $15-21$

Vabø R, Nøttestad L (1997) An individual based model of fish school reactions: predicting antipredator behaviour as observed in nature. Fish Oceanogr 6:155-171

Wrzesinski O (1972) A study on schooling patterns of the Barents Sea capelin and North Sea haddock. ICES Comm Meet (Gear Behav Comm) 1972/B:8

Submitted: January 21, 2000; Accepted: May 11, 2000

Proofs received from author(s): September 27, 2000 